\title{
Analisis Faktor-Faktor Penyebab Terjadinya Pengangguran dan Urbanisasi Pemuda di Desa Tamansari Kecamatan Karangmoncol Kabupaten Purbalingga Provinsi Jawa Tengah
}

\author{
Placenta Abshar Wijaya*1, John Suprihanto², Bagus Riyono ${ }^{3}$ \\ Sekolah Pascasarjana \\ Universitas Gadjah Mada \\ Yogyakarta, Indonesia
}

e-mail: placenta.abshar@gmail.com¹,johnsuprihanto@ugm.ac.id², bagus@ugm.ac.id ${ }^{3}$

\section{Riwayat Artikel Tanggal diajukan: 20 April 2020 \\ Tanggal diterima 2 Juni 2020 \\ Tanggal dipublikasikan: 29 Juni 2020}

Pengutipan: Wijaya, P. A., Suprihanto, J. \& Riyono, B. (2020) Analisis Faktor-

Faktor Penyebab

Terjadinya

Pengangguran

dan Urbanisasi

Pemuda di Desa

Tamansari

Kecamatan

Karangmoncol

Kabupaten

Purbalingga

Provinsi Jawa

Tengah

Jurnal Pendidikan

Ekonomi

Undiksha, 12 (1),

117-129

\section{Abstrak}

Salah satu permasalahan yang sering terjadi di desa adalah masalah pengangguran dan urbanisasi, khususnya yang terjadi di kalangan pemuda Desa Tamansari, Kecamatan Karangmoncol, Kabupaten Purbalingga, Provinsi Jawa Tengah. Tujuan dari penelitian ini adalah (1) Mengidentifikasi faktor-faktor yang menyebabkan terjadinya pengangguran dan urbanisasi di kalangan pemuda Desa Tamansari, Kecamatan Karangmoncol, Kabupaten Purbalingga, Provinsi Jawa Tengah, (2) Menganalisis penyebab terjadinya faktor-faktor pengangguran dan urbanisasi di kalangan pemuda Desa Tamansari, Kecamatan Karangmoncol, Kabupaten Purbalingga, Provinsi Jawa Tengah. Jenis penelitian ini adalah deskriptif kualitatif. Narasumber dalam penelitian ini yakni pemuda Desa Tamansari dan Kepala Desa Tamansari. Teknik pengumpulan data dalam penelitian ini menggunakan teknik wawancara, observasi, dokumentasi, dan penelusuran data online. Alat analisis dalam penelitian ini menggunakan alat analisis deskriptif kualitatif dan alat analisis komparatif. Hasil penelitian menunjukan bahwa (1) Terdapat faktor-faktor yang menyebabkan terjadinya pengangguran dan urbanisasi di kalangan pemuda Desa Tamansari, Kecamatan Karangmoncol, Kabupaten Purbalingga, Provinsi Jawa Tengah, (2) Diperoleh beberapa penyebab terjadinya faktor-faktor pengangguran dan urbanisasi di kalangan pemuda Desa Tamansari, Kecamatan Karangmoncol, Kabupaten Purbalingga, Provinsi Jawa Tengah

Kata kunci: pemuda; pengangguran; urbanisasi

\begin{abstract}
Some of the problems that are frequently found in villages are unemployment and urbanization, especially among young people in Tamansari Village, Karangmoncol Subdistrict, Purbalingga Regency, Central Java Province. This study aimed to (1) Identify the factors that cause unemployment and urbanization among the youth in Tamansari Village, Karangmoncol Subdistrict, Purbalingga Regency, Central Java Province, (2) Analyze the causes of unemployment and urbanization among the youth in Tamansari Village, Karangmoncol Subdistrict, Purbalingga Regency, Central Java Province. This was a qualitative descriptive study. The informants in this study were the young people in Tamansari Village, and the Head of Tamansari Village. The data were collected through interview, observation, documentation, and online data search techniques. The analysis in this study was carried out using descriptive qualitative analysis and comparative analysis. The results of the study showed that (1) There are some factors that cause unemployment and urbanization among the youth in Tamansari Village, Karangmoncol Subdistrict, Purbalingga Regency, Central Java Province, (2) Several causes of unemployment and urbanization among the youth in Tamansari Village, Karangmoncol Subdistrict, Purbalingga Regency, Central Java Province were revealed.
\end{abstract}

Keywords : youth; unemployment; urbanization 


\section{PENDAHULUAN}

Manusia pada saat ini sedang memasuki era persaingan global, oleh karena itu tidak hanya kerja keras, melainkan manusia yang mampu untuk kerja cerdas dan memiliki potensi lebih maka akan mampu memenangkan persaingan global (Hidayat, 2016: 77). Oleh karena itu ketatnya persaingan pada saat ini secara tidak langsung juga berpengaruh terhadap ketatnya persaingan dalam memperoleh lapangan pekerjaan, sehingga hanya manusia dengan potensi lebih yang akan memperoleh pekerjaan. Sulitnya memperoleh lapangan pekerjaan pada saat ini adalah bentuk dari pola fikir manusia yang selalu berlomba-lomba untuk mencari pekerjaan ditengah terbatasnya lapangan pekerjaan (Ramdani, 2014: 111). Semakin terbatasnya lapangan pekerjaan, khususnya di wilayah pedesaan, maka akan semakin tinggi tingkat pengangguran dan urbanisasi di kalangan masyarakat desa, tentu saja ini tidak sesuai dengan salah satu misi NKRI (Negara kesatuan republik Indonesia) yang tertuang pada pembukaan UUD (UndangUndang Dasar) 1945 yakni dalam hal memajukan kesejahteraan umum.

Data BPS (Badan Pusat Statistik) per

5 Mei 2020 menunjukan angka pengangguran terbuka masyarakat desa mengalami peningkatan, yakni 3,45 persen pada Tahun 2019 menjadi 3.55 persen pada Tahun 2020 (Katadata, 2020). Kemudian dari pada itu, tingkat urbanisasi Indonesia yang tercatat oleh Bank dunia per Tahun 2017 berada pada angka 55 persen dari total keseluruhan jumlah masyarakat Indonesia, itu artinya dari total jumlah keseluruhan masyarakat Indonesia yakni 264 juta jiwa terdapat 144 juta masyarakat Indonesia yang tinggal di daerah urban, angka tersebut termasuk tertinggi kedua di kawasan Asia tenggara dibawah Malaysia yang berada diperingkat pertama dengan angka 75,4 persen tingkat urbanisasi (Katadata, 2019).

Permasalahan pengangguran dan urbanisasi di desa bukan hanya menjadi sebuah permasalahan yang biasa, karena apabila dibiarkan akan berdampak pada tidak produktifnya desa akibat dari tidak adanya aktivitas-aktivitas yang dapat menghasilkan nilai ekonomis di wilayah pedesaan. Desa Tamansari, Kecamatan Karangmoncol, Kabupaten Purbalingga, Provinsi Jawa Tengah menjadi salah satu desa dari 83.931 desa yang ada di Indonesia yang mengalami masalah pengangguran dan urbanisasi, khusunya dikalangan para pemuda. Berdasarkan data survey pengangguran dan urbanisasi yang peneliti lakukan terhadap 337 pemuda Desa Tamansari, menunjukan bahwa 35.2 persen atau 118 pemuda Desa tidak bekerja atau menganggur, sedangkan data 64.8 persen atau 219 pemuda Desa melakukan urbanisasi/ meninggalkan Desa, sehingga dalam hal ini perlu sekali menggali informasi terkait faktor-faktor yang menyebabkan permasalahan tersebut terjadi. Oleh karena itu, penelitian ini dilakukan dengan tujuan (1) Mengidentifikasi faktor-faktor yang menyebabkan terjadinya pengangguran dan urbanisasi di kalangan pemuda Desa Tamansari, Kecamatan Karangmoncol, Kabupaten Purbalingga, Provinsi Jawa Tengah, (2) Menganalisis penyebab terjadinya faktor-faktor pengangguran dan urbanisasi di kalangan pemuda Desa Tamansari, Kecamatan Karangmoncol, Kabupaten Purbalingga, Provinsi Jawa Tengah.

\section{LANDASAN TEORI \\ Teori Pengangguran \\ Menurut Kaufman dan Hotchkiss, 1999 (dalam Dongoran dkk, 2016: 64)} menyatakan bahwa pengangguran adalah suatu tolak ukur yang dilakukan terhadap seseorang yang tidak memiliki pekerjaan tetapi sedang berusaha secara aktif selama empat minggu terakhir untuk mencari suatu pekerjaan. Selain itu, pengangguran merupakan suatu kondisi seseorang masuk dalam golongan angkatan kerja yang ingin memperoleh pekerjaan tetapi belum memperoleh pekerjaan tersebut (Sukirno, 1994). Pengangguran terbuka merupakan suatu pengangguran yang disebabkan oleh seseorang lebih memilih tidak bekerja demi mendapatkan pekerjaan yang lebih baik maupun seseorang yang ingin bekerja tetapi tidak memperoleh pekerjaan (Dongoran, 2016: 65). JenisJenis Penggangguran menurut Sukirno (2008: 328-331) berdasarkan ciri-cirinya yakni sebagai berikut: 
a. Pengangguran Musiman, adalah kondisi seseorang menganggur karena adanya suatu kegiatan ekonomi dalam jangka pendek. Sebagai contoh yakni petani yang sedang menanti musim tanam, penjual durian yang sedang menanti musim durian.

b. Pengangguran Terbuka adalah suatu pengangguran yang terjadi akibat kesediaan lapangan kerja yang jauh lebih rendah dibandingkan jumlah pencari kerja.

c. Pengangguran Tersembunyi adalah pengangguran yang diakibatkan jumlah pekerja lebih banyak dari jumlah pekerja yang dibutuhkan, sehingga diperlukan efisien tenaga kerja dalam kegiatan ekonomi.

d. Setengah Menganggur adalah seorang pekerja yang yang memiliki jam kerja dibawah jam kerja normal yakni hanya 1sampai 4 jam sehari.

\section{Teori Urbanisasi}

Urbanisasi menurut Shogo Kayono (dalam Harahap, 2013: 36) memiliki pengertian yakni perpindahan penduduk dari desa ke kota atas suatu latar belakang yakni ekonomi, sosial, politik, dan budaya. Adapun faktor-faktor yang mengakibatkan tejadinya urbanisasi menurut (Tjiptoherijanto, 1999: 62) adalah tersedianya sumber pekerjaan di kota, perkembangan ekonomi di kota, keinginan untuk mendirikan usaha di kota demi memperoleh kesejahteraan, dan hal tersebut tidak akan diperoleh apabila berada di desa (Rural).

\section{Teori Pemuda}

Bangsa Indonesia merupakan bangsa yang besar yang lahir dari perjuangan para pahlawan dalam melawan penjajah. Dalam konteks pahlawan, pada zaman dahulu para pahlawan Indonesia banyak didominasi oleh kaum pemuda dalam memperjuangkan kemerdekaan. Oleh karena itu pemuda merupakan sumber perubahan suatu negara dimasa yang akan datang. Berdasarkan undang-undang nomor 40 tahun 2009 yang dimaksud pemuda adalah seseorang yang berusia antara 16 tahun sampai 30 tahun. Pemuda berdasarkan amanah undang-undang tersebut harus mampu menjadi pemuda yang memiliki jiwa kewirausahaan, berakhlak mulia, sehat, kreatif, inovatif, mandiri, dan mampu menjadi pelopor kemajuan bangsa

\section{METODE}

Penelitian ini yang berjudul "Analisis Faktor-Faktor Penyebab Terjadinya Pengangguran Dan Urbanisasi Pemuda Desa Tamansari, Kecamatan Karangmoncol, Kabupaten Purbalingga, Provinsi Jawa Tengah", termasuk jenis penelitian deskriptif kualitatif yakni sebuah penelitian yang menghasilkan data deskriptif berupa kata-kata atau lisan, catatan, dan lebih mampu menyesuaikan dengan kondisi di lapangan (Fransiska, 2018: 54). Pengumpulan data dalam penelitian deskriptif kualitatif dapat disesuaikan dengan masalah, tujuan, dan obyek yang akan diteliti (Fransiska, 2018: 56). Oleh karena itu, adapun data pada penelitian ini terbagi menjadi dua yakni data primer dan data sekunder. Data primer yakni berupa data yang diperoleh dari wawancara dan observasi. Data sekunder berupa data yang diperoleh dari dokumentasi dan penelusuran data online atau internet (Nugroho, 2018: 39).

Alat analisis data yang digunakan untuk pertanyaan dan tujuan penelitian nomor satu adalah analisis data deskriptif kualitatif. Alat analisis data yang digunakan untuk pertanyaan dan tujuan penelitian nomor dua adalah analisis data komparatif. Menurut Miles dan Huberman (dalam Fransiska, 2018: 59) mengungkapkan bahwa semua analisis data tersebut memiliki 4 tahap, adapun tahapanya yakni pengumpulkan data, reduksi data, menyajikan data, dan penarikan kesimpulan. Kemudian dari pada itu, penelitian ini sebatas untuk menganalisis faktor-faktor penyebab terjadinya pengangguran dan urbanisasi pemuda Desa Tamansari, Kecamatan Karangmoncol, Kabupaten Purbalingga, Provinsi Jawa Tengah.

\section{HASIL DAN PEMBAHASAN}

Profil Desa Tamansari

Desa Tamansari merupakan salah satu Desa dari 11 Desa yang berada di Kecamatan Karangmoncol, Kabupaten 
Purbalingga. Desa Tamansari memiliki luas wilayah sebesar 590 hektar, 148 hektar untuk tanah persawahan dan 442 hektar untuk tanah kering. Desa Tamansari memiliki ketinggian 300 meter di atas permukaan air laut. Jarak antara Desa Tamansari dengan Kecamatan Karangmoncol adalah 4 kilometer, sedangkan jarak antara Desa Tamansari Dengan Kabupaten Purbalingga adalah 26 kilometer. Adapun batas wilayah Desa Tamansari dengan Desa di sekitarnya adalah sebagai berikut:

Tabel 1.1. Batas Wilayah Desa Tamansari

\begin{tabular}{lll}
\hline Desa & Batas & \multicolumn{2}{c}{ Wilayah } \\
\hline & Utara & $\begin{array}{l}\text { Desa Tunjungmuli, } \\
\text { Desa Kramat, } \\
\text { Desa Sirau }\end{array}$ \\
\cline { 2 - 4 } Tamansari & Timur & $\begin{array}{l}\text { Desa Rajawana, } \\
\text { Desa Tajug }\end{array}$ \\
\cline { 2 - 4 } & Selatan & $\begin{array}{l}\text { Desa Pekringan, } \\
\text { Desa Grantung, } \\
\end{array}$ \\
\cline { 2 - 4 } & Desa Pepedan \\
\hline
\end{tabular}

Sumber: BPS Kabupaten Purbalingga Tahun 2018.

Kemudian dari pada itu apabila dilihat dari susunan pemerintahan, Desa Tamansari dipimpin oleh 1 orang kepala Desa dan 5 orang kaur Desa. Desa Tamansari juga memiliki 5 dusun, 19 RW (Rukun Warga), dan 42 RT (Rukun Tetangga). Berdasarkan profil kependudukan, Desa Tamansari memiliki jumlah penduduk yakni 6809 penduduk, dengan rincian 3469 penduduk berjenis kelamin laki-laki dan 3340 penduduk berjenis kelamin perempuan. Menurut keyakinan yang dianut oleh penduduk Desa Tamansari, seluruh penduduk Desa Tamansari memiliki keyakinan beragama Islam. Kemudian jika di bandingkan dengan tahun 2016, laju pertumbuhan penduduk Desa Tamansari mengalami kenaikan 8,60 persen atau 6270 penduduk ditahun 2016 menjadi 6809 penduduk ditahun 2017.

Desa tamansari memiliki luas wilayah yang kurang lebih 30 persen wilayahnya didominasi oleh lahan pertanian, oleh karena itu rata-rata masyarakat Desa Tamansari memiliki mata pencaharian sebagai petani atau buruh tani. Selain itu tidak sedikit masyarakat Desa Tamansari yang memilih merantau keluar desa untuk menjadi buruh industri, buruh bangunan, ataupun pedagang.

Tabel 1.2. Kondisi Mata Pencaharian Masyarakat Desa Tamansari 10 Tahun Keatas Tahun 2016

\begin{tabular}{clll}
\hline Desa & \multicolumn{1}{c}{$\begin{array}{c}\text { Jenis } \\
\text { Pekerjaan }\end{array}$} & Jumlah & \multicolumn{1}{c}{$\begin{array}{c}\text { Persenta } \\
\text { se }\end{array}$} \\
\hline \multirow{1}{*}{$\begin{array}{l}\text { Taman } \\
\text { sari }\end{array}$} & Petani & 947 & $19.9 \%$ \\
\cline { 2 - 4 } & Buruh tani & 1009 & $21.2 \%$ \\
\cline { 2 - 4 } & $\begin{array}{l}\text { Buruh } \\
\text { industri }\end{array}$ & 957 & $20.1 \%$ \\
\cline { 2 - 4 } & Bangunan & 750 & $15.7 \%$ \\
\cline { 2 - 4 } & Nelayan & 0 & $0 \%$ \\
\cline { 2 - 4 } & Pengusaha & 70 & $1.47 \%$ \\
\cline { 2 - 4 } & Pedagang & 602 & $12.6 \%$ \\
\cline { 2 - 4 } & Angkutan & 38 & $0.8 \%$ \\
\cline { 2 - 4 } & PNS & 148 & $3.11 \%$ \\
\cline { 2 - 4 } & ABRI & 2 & $0.04 \%$ \\
\cline { 2 - 4 } & Pensiunan & 71 & $1.49 \%$ \\
\cline { 2 - 4 } & Lainnya & 155 & $3.26 \%$ \\
\hline \multirow{2}{*}{ Total Pekerja } & 4749 & $100 \%$
\end{tabular}

Sumber: BPS Kabupaten Purbalingga Tahun 2017.

Berdasarkan data mata pencaharian masyarakat Desa Tamansari di atas, menunjukan bahwa sektor pertanian menjadi sektor pekerjaan utama masyarakat Desa Tamansari yakni berkisar pada angka 41.1 persen. Kemudian dari pada itu, Kondisi pendidikan di Desa Tamansari dapat dikatakan baik, hal tersebut dikarenakan Desa Tamansari memiliki instansi pendidikan yang lengkap dari beberapa jenjang. Desa tamansari memiliki 5 buah TK (Taman Kanak-Kanak), 6 buah SD (Sekolah dasar), 3 SMP (Sekolah Menengah Pertama), dan 1 buah MA (Madrasah Aliyah).

\section{Realita Pengangguran Dan Urbanisasi}

Pengangguran secara tidak langsung menjadi awal mula terjadinya urbanisasi. Hal tersebut dikarenakan ketika seseorang tidak memperoleh pekerjaan yang 
diinginkan, orang tersebut lebih memilih untuk tidak bekerja dan kemudian akan berdampak pada tidak terpenuhinya kebutuhan ekonomi. Kebutuhan ekonomi yang tidak terpenuhi akan menyebabkan seseorang untuk pergi ke suatu tempat yang memungkinkan akan merubah kondisi ekonomi tersebut menjadi lebih baik. Hal tersebutlah yang terjadi di kalangan pemuda Desa Tamansari, Kecamatan Karangmoncol, Kabupaten Purbalingga. Berdasarkan wawancara yang peneliti lakukan dengan Lastuti selaku kepala Desa Tamansari, Lastuti menyatakan bahwa beberapa pemuda desa setelah menyelesaikan pendidikan menengah atas tidak bekerja atau menganggur. Adapun kutipan wawancaranya sebagai berikut:

"Betul, banyak sekali anak-anak muda di desa yang sudah tamat sekolah kemudian tidak melanjutkan kuliah atau bekerja, malah nongkrongnongkrong ndak jelas (Wawancara Kepala Desa Tamansari, Lastuti, pada 25 Februari 2019, Pukul 17.50 WIB)."

Oleh karena itu, berdasarkan Informasi di atas menunjukan bahwa pengangguran di kalangan pemuda Desa memang benar adanya terjadi. Urbanisasi adalah suatu perpindahan penduduk dari desa ke kota, hal tersebut terjadi karena dipengaruhi oleh beberapa faktor. Terkait dengan realita urbanisasi di Desa Tamansari Kabupaten Purbalingga, sebagian besar urbanisasi dilakukan oleh para pemuda yang telah menamatkan pendidikan dari sekolah menengah atas. Realita pemuda desa yang melakukan urbanisasi setelah menamatkan diri dari pendidikan menengah atas diperoleh berdasarkan hasil wawancara dengan pemuda Desa Tamansari. Adapun kutipan wawancara tersebut yakni sebagai berikut:

"lya mas rata-rata yang lulus dari desa langsung ke luar kota. Kalau di sini biasalah rata-rata pemuda desa merantau ke Jakarta. (Wawancara pemuda Desa Tamansari, Zaenal Sukri, pada 25 Februari 2019, Pukul 16.20 WIB)."
Hasil wawancara tersebut juga dibenarkan oleh Kepala Desa Tamansari, Lastuti. Lastuti menyampaikan bahwa memang benar adanya sebagian besar pemuda desa yang ada di Desa Tamansari setelah menyelesaikan pendidikan formal, lebih memilih untuk meninggalkan desa dan merantau ke beberapa kota besar yang ada di Indonesia. Informasi tersebut peneliti peroleh berdasarkan hasil wawancara dengan Lastuti selaku Kepala Desa Tamansari. Kutipan wawancara tersebut yakni sebagai berikut:

"Rata-rata seperti itu, jadi setelah tamat langsung ke luar kota, dan kebanyakan pemuda di desa ini memang seperti itu (Wawancara Kepala Desa Tamansari, Lastuti, pada 25 Februari 2019, Pukul 17.50 WIB)."

Sehingga berdasarkan informasi wawancara tersebut, dapat diambil sebuah kesimpulan bahwasannya memang benar adanya pemuda Desa Tamansari, Kecamatan Karangmoncol, Kabupaten Purbalingga setelah lulus dari pendidikan formal, memilih merantau ke Kota dan meninggalkan Desa atau kampung halaman.

\section{Faktor-Faktor Penyebab Pengangguran} Dan Urbanisasi di Kalangan Pemuda Desa

Terdapat beberapa faktor yang menyebabkan terjadinya pengangguran di suatu wilayah, khususnya terkait penyebab pengangguran di kalangan pemuda Desa Tamansari, Kecamatan Karangmoncol, Kabupaten Purbalingga. Terdapat beberapa

Faktor-faktor yang melatarbelakangi terjadinya pengangguran di kalangan pemuda Desa Tamansari, adapun faktorfaktor penyebab pengangguran tersebut diperoleh dari hasil wawancara dengan beberapa informan. Salah satunya adalah wawancara bersama Nofi Bayu Darmawan selaku pengusaha muda di Desa Tamansari, adapun kutipan wawancara tersebut yakni sebagai berikut:

"Jadi alasan kenapa anak-anak non produktif atau nganggur setalah tamat SMA mas, karena mereka tidak melanjutkan pendidikan ke jenjang 
perguruan tinggi, jadi itu yang membuat masih banyaknya pemuda non-produktif pasca lulusan SMA. Selain itu mas, Meskipun dengan profil wilayah yang mayoritas orang tua bermata pencaharian tani dan buruh tani, para pemuda di zaman sekarang tidak mau untuk terjun dalam dunia pertanian mas (Wawancara dengan pengusaha di Desa Tamansari, Nofi Bayu Darmawan, pada 6 Desember 2018, Pukul 16.00 WIB)."

Hal serupa juga disampaikan oleh Kepala Desa Tamansari guna memeperkuat informasi yang peneliti peroleh dari Nofi Bayu Darmawan selaku pengusaha muda di Desa Tamansari. Informasi tersebut yakni sebagai berikut:

"Ya kalau masalah tingkat pengangguran di desa menurut saya begini, anak sekarang kan kerja-kerja tani kan sudah pada ndak mau, contohnya bapaknya kerja petani tetapi anak sekarang kan ndak tertarik kerja jadi petani. terus pemuda setelah tamat sekolah kebanyakan tidak melanjutkan, dan rata-rata bingung mau apa terus akhirnya nganggur. (Wawancara Kepala Desa Tamansari, Lastuti, pada 25 Februari 2019, Pukul 17.50 WIB)."

Sehingga berdasarkan informasi
tersebut, dapat disimpulkan bahwa penyebab utama para pemuda di Desa Tamansari menganggur atau tidak produktif pasca menamatkan SMA (Sekolah Menengah Atas) yakni karena tidak melanjutkan kejenjang perguruan tinggi, selain itu juga ketidakmauan para pemuda untuk bekerja di sektor pertanian, meskipun para pemuda sebagian besar memiliki orang tua yang mayoritas bekerja sebagai petani. Hal tersebut sesuai dengan teori yang disampaikan oleh Dongoran (2016:65) yang menyatakan bahwa seseorang lebih memilih tidak bekerja demi mendapatkan pekerjaan yang lebih baik.

Kemudian dari pada itu, terkait dengan faktor-faktor penyebab terjadinya urbanisasi pemuda Desa Tamansari,
Terdapat beberapa faktor-faktor yang melatarbelakangi terjadinya urbanisasi tersebut. Adapun faktor-faktor penyebab terjadinya urbanisasi tersebut diperoleh dari hasil wawancara dengan beberapa informan. Salah satunya adalah wawancara bersama Nofi Bayu Darmawan selaku pengusaha muda di Desa Tamansari, adapun kutipan wawancara tersebut yakni sebagai berikut:

"Sedikitnya yang membuka lapangan pekerjaan di tingkat Desa/ Kecamatan mas, jadi menutup kesempatan untuk para pemuda bekerja Kampung Halaman. Kebanyakan dari mereka mayoritas merantau ke Kota karena berburu lapangan pekerjaan yang layak dan lebih mudah didapatkan. Hal ini juga membuat tidak bergeraknya organisasi-organisasi pemuda yang menghidupkan Desa mas (Wawancara pengusaha muda di Desa Tamansari, Nofi Bayu Darmawan, pada 6 Desember 2018, Pukul 16.00 WIB)."

Informasi tersebut diperkuat oleh beberapa informasi yang diperoleh secara langsung dari pemuda Desa Tamansari bahwa alasan utama mereka melakukan urbanisasi adalah untuk memperoleh suatu pekerjaan di kota, hal tersebut dikarenakan masih minimnya lapangan pekerjaan di desa. Adapun kutipan wawancara dengan pemuda desa yakni sebagai berikut:

"Saya merantau kerja di Kota. karena ketersediaan lapangan kerja di sini masih susah dan minim, tidak sebesar di Kota, dan lapangan kerja di desa juga belum ada (Wawancara dengan pemuda Desa Tamansari, Zaenal Sukri, pada 25 Februari 2019, Pukul 16.20 WIB)."

"Saya merantau karena kerja dagang diluar Kota, kerja di Kota Depok. Itu karena lapangan kerja di desa juga belum ada. (Wawancara dengan pemuda Desa Tamansari, Afid Solikhin, pada 25 Februari 2019, Pukul 16.03 WIB)." 
"Saya kerja di PT Royal Purbalingga. Karena lapangan kerja di Desa juga kurang (Wawancara dengan pemuda Desa Tamansari, Endah Saputri Ningsih, pada 25 Februari 2019, Pukul 16.38 WIB)."

Kepala Desa Tamansari juga membenarkan bahwa alasan utama pemuda desa melakukan urbanisasi adalah untuk mendapatkan sebuah pekerjaan, akibat masih minimnya lapangan pekerjaan di Desa Tamansari, adapun kutipan wawancara tersebut yakni sebagai berikut:

"Ya, anak-anak muda di sini larinya nyari kerja di Kota-Kota besar, seperti di beberapa perusahaan asing di Kota. Sebelumnya peluang kerja industri di desa apa ya? Saya juga belum melihat peluang kerja industri di Desa (Wawancara Kepala Desa Tamansari, Lastuti, pada 25 Februari 2019, Pukul 17.50 WIB)."

Sehingga dapat diperoleh kesimpulan bahwasanya faktor-faktor yang menyebabkan terjadinya tingkat urbanisasi di kalangan pemuda Desa Tamansari yakni perihal untuk memperoleh suatu pekerjaan di kota, selain itu juga akibat dari minimnya ketersediaan lapangan pekerjaan di Desa Tamansari. Hal tersebut sesuai dengan teori urbanisasi yang disampaikan oleh Tjiptoherijanto (1999:62) menyatakan bahwa urbanisasi terjadi karena tersedianya sumber pekerjaan di kota, dan hal tersebut tidak akan diperoleh apabila berada di desa (Rural).

Penyebab Terjadinya Faktor-Faktor Pengangguran Dan Urbanisasi Di Kalangan Pemuda Desa

Penyebab Faktor Tidak Melanjutkan Ke Peruguruan Tinggi

Pendidikan ke jenjang perguruan tinggi merupakan suatu cara seseorang dalam meraih masa depan yang lebih baik, sehingga setiap tahunnya para siswa lulusan sekolah menengah atas akan berlomba-lomba untuk bersaing diterima di perguruan tinggi favorit masing-masing. Pendidikan ke jenjang perguruan tinggi tidak bisa dilepaskan dari faktor ekonomi, karena faktor ekonomi sangat berpengaruh terhadap kelanjutan pendidikan seseorang tersebut. Khususnya para pemuda Desa Tamansari, Kecamatan Karangmoncol, Kabupaten Purbalingga, adapun faktor yang menyebabkan para pemuda tidak melanjutkan ke jenjang pendidikan yang lebih tinggi karena dilatarbelakangi masalah faktor ekonomi. Faktor ekonomi yang dimaksud adalah keterbatasan biaya yang dipergunakan untuk melanjutkan pendidikan ke jenjang perguruan tinggi.

Para pemuda menuturkan bahwa untuk melanjutkan ke jenjang perguruan tinggi sangat diperlukan biaya yang tidak sedikit, oleh karena itu para pemuda lebih mimilih untuk tidak melanjutkan pendidikan ke jenjang perguruan tinggi, sehingga karena hal tersebutlah yang menyebabkan para pemuda menganggur dan hingga akhirnya memilih untuk bekerja ke kota, karena menganggur lama di desa bukan sebuah pilihan. Informasi tersebut berdasarkan keterangan yang peneliti peroleh melalui wawancara dengan beberapa pemuda terkait tidak melanjutkannya ke jenjang perguruan tinggi, adapun kutipan wawancara tersebut yakni sebagai berikut:

"Saya tidak melanjutkan pendidikan ke jenjang berikutnya karena latar belakang ekonomi keluarga saya yang kurang mampu, orang tua saya tidak punya cukup biaya untuk kuliah saya jadi saya memilih untuk bekerja di Kota meskipun sebelumnya sempat nganggur, untuk membantu perekonomian keluarga. Saya pernah mencoba beasiswa bidik misi, itu juga karena saran dari guru-guru saya, namun saya tidak lolos seleksi SNMPTN dan saya tidak melanjutkan jalur tes, dan saya lebih memilih bekerja (Wawancara dengan Endah Kusuma Ningsih pada 10 April 2019 Pukul 18.19 WIB)".

Informasi dari Endah Kusuma Ningsih tersebut didukung oleh informasi yang diperoleh dari pemuda lainnya yakni Afid Solikhin, yakni sebagai berikut: 
"Kenapa tidak melanjutkan kuliah ya mungkin banyak faktor ya, mungkin dari dana, mungkin susah karena di Desa agak lumayan susah untuk jenjang kuliah itu, dananya lumayan tinggi ya jadi ya saya dulu masih fikirfikir dulu. Niatnya sih kalau pingin kuliah itu semua anak ya pasti mau, tapi kan harus mikir ulang gimana keadaan orang tua, gimana keuangannya, jadi ya saya fikir-fikir dulu (Wawancara dengan Afid Solikhin pada 10 April 2019 pukul 18.48 WIB)".

Sehingga dapat ditarik sebuah kesimpulan, bahwasanya alasan utama pemuda Desa Tamansari tidak melanjutkan ke jenjang perguruan tinggi yakni karena faktor masalah ekonomi keluarga yang tidak memadai untuk membiayai ke jenjang perguruan tinggi, hal tersebut sesuai dengan teori yang disampaiakan oleh Barkowsky dan Thorpe (dalam Pujianto dkk, 2015:3) yang menyatakan bahwa anakanak yang berasal dari latar belakang sosial ekonomi yang lebih rendah biasanya menampilkan motivasi akademis dan prestasi yang lebih rendah, dan resiko mengalami kegagalan bersekolah dan putus sekolah yang lebih besar.

\section{Penyebab Faktor Tidak Bersedia Bekerja Sebagai Petani}

Salah satu faktor yang menyebabkan terjadinya pengangguran di kalangan pemuda Desa Tamansari adalah para pemuda tidak bersedia untuk bekerja di sektor pertanian, sehingga atas latarbelakang tersebut para pemuda lebih memilih menganggur ketika berada di desa meskipun pada akhirnya merantau ke luar kota. Terdapat beberapa alasan mengapa para pemuda tidak mau untuk bekerja di sektor pertanian, diantaranya yakni sektor pertanian bukan merupakan pekerjaan yang menarik di kalangan pemuda, Informasi tersebut peneliti peroleh berdasarkan keterangan dari wawancara dengan pemuda desa, adapun kutipan wawancara tersebut yakni sebagai berikut:

"Saya tidak menjadi petani karna 90 persen lebih yang ada disini anak muda tidak ada yang jadi petani, saya lihat malah belum ada lho yang bekerja sebagai petani, karena disini rata-rata petani itu yang sudah berkeluarga dan rata-rata itu yang menjadi petani sekitar 40 tahun ketas, kalau 30 tahun kebawah itu belum ada, apalagi yang seperti saya masih 19 tahun itu kayaknya belum ada di daerah Tamansari. Saya malah pengenya ada ide baru dari pemerintah untuk memajukan sektor pertanian supaya saya dan anak muda disini tertarik kerja di sektor pertanian, seperti penggunaan teknologi canggih di sektor pertanian seperti pertanian yang ada luar negeri yang mulai berkembang pesat, tapi kalau melihat keadaan yang sekarang ini yang masih manual jadi saya agak kurang tertarik kerja di sektor pertanian. Gaji kecil petani juga berpangaruh mas, jadi harus ada ide yang berkembang supaya para pemuda itu gak usah jauh-jauh kerja di kota atau gimana, cukup pertanian jika berkembang pakai ide-ide baru untuk memajukan sektor pertanian ya siapa tahu malah justru gaji atau pendapatan petani juga bisa tinggi (Wawancara dengan Afid Solikhin pada 10 April 2019 pukul 18.48 WIB)".

Informasi dari Afid Sholikin tersebut didukung oleh informasi yang diperoleh dari pemuda lainnya yakni Endah Kusuma Ningsih, yakni sebagai berikut:

"Saya tidak bekerja di sektor pertanian karena memang saya tidak berbakat dan berminat di sektor pertanian, alasanya selain saya tidak punya cukup ilmu untuk bertani, penghasilan menjadi petani juga sedikit, dan disini rata-rata memang pemuda jarang sekali, bahkan dibilang tidak ada yang kerja di sektor pertanian kebanyakan orang tua, jadi mungkin karena mengikuti kebiasaan. Jadi itu yang jadi alasan saya nganggur hingga akhirnya memutuskan lebih memilih bekerja di industri-industri lain yang penghasilanya lebih besar karena 
untuk mencukupi kebutuhan hidup yang semakin hari semakin banyak (Wawancara dengan Endah Kususma Ningsih pada 10 April 2019 pukul 18.19 WIB)".

Sehingga berdasarkan informasi tersebut diperoleh beberapa pembahasan bahwasanya para pemuda tidak tertarik untuk bekerja di sektor pertanian dikarenakan sektor pertanian di Desa Tamansari tidak mampu memberikan jaminan masa depan yang lebih baik, karena kecilnya penghasilan yang diperoleh dari sektor pertanian. Kemudian dari pada itu jika melihat data, menurut peneliti Institut Pembangunan Ekonomi dan Keuangan (Indef) Imaduddin Abdullah menyatakan bahwa berdasarkan sensus terakhir pada 2017 rata-rata pendapatan petani di Indonesia hanya mencapai 12,4 juta Rupiah per tahun, sehingga per bulan pendapatannya hanya 1 juta Rupiah (Okezone.com). Jika berdasarkan data BPS Januari 2019, rata-rata penghasilan buruh tani sebesar Rp 54.604 perhari atau setara 1,68 juta Rupiah dalam sebulan (CNN Indonesia), sehingga berdasarkan data penghasilan rata-rata petani atau buruh tani Indonesia tersebut, masih dibawah UMK Purbalingga pada tahun 2019 yakni pada nominal Rp 1.788.500,00-.

Kemudian dari pada itu, berdasarkan hasil wawancara di atas, sektor pertanian di Desa Tamansari dipandang sebagai pekerjaan yang biasa dikerjakan oleh orang-orang tua dan sudah berkeluarga. Sektor pertanian juga dianggap tidak sesuai dengan keinginan pemuda diera sekarang yang serba menggunakan teknologi modern, sehingga para pemuda mengharapkan kemajuan teknologi modern dapat berperan di sektor pertanian khususnya pertanian Desa Tamansari, hal tersebut dikarenakan aktivitas pekerjaan di sektor pertanian Desa Tamansari masih bersifat manual dan belum menggunkan teknologi modern layaknya sektor pertanian yang ada di beberapa Negara lain seperti Korea, Jepang, dan Tiongkok.

Sehingga dalam hal ini peran pemerintah sangat diperlukan dalam mewujudkan sektor pertanian menjadi sektor favorit guna menarik minat pemuda dalam memilih pekerjaan. Kesimpulan diatas sesuai dengan teori yang disampaikan oleh Susilowati (2016:47) yang menyatakan bahwa terdapat berbagai faktor yang menyebabkan sektor pertanian tidak diminati oleh generasi muda, seperti anggapan pertanian kurang memberikan kelanjutan pendapatan, tingkat upah atau pendapatan di sektor pertanian yang rendah terutama dengan status petani gurem, tidak berkembangnya sektor pertanian serta industri pertanian yang ada di Desa, dan belum adanya insentif khusus untuk petani muda dan pemula.

\section{Penyebab Faktor Minimnya Lapangan Kerja Di Desa}

Minimnya lapangan pekerjaan di Desa Tamansari dipengaruhi oleh beberapa faktor. Jika melihat data mata pencaharian masyarakat Desa Tamansari berdasarkan Badan Pusat Statistik Kabupaten Purbalingga Tahun 2017, hampir sebagian besar masyarakat di Desa Tamansari bekerja di sektor pertanian yakni sekitar 41.1 persen, hal tersebut dikarenakan wilayah Desa Tamansari sekitar 30 persen lebih merupakan lahan pertanian, hal tersebut menunjukan bahwa Desa Tamansari secara mayoritas mengandalkan sektor pertanian sebagai sumber pekerjaan utama sebagaian besar masyarakat Desanya. Meskipun sektor pertanian menjadi sektor utama masyarakat Desa Tamansari dalam mencari sumber penghasilan, ironinya sektor pertanian kurang diminati oleh para pemuda desa. Para pemuda desa lebih berminat untuk bekerja di berbagai industri yang terdapat di kota. Jika berdasarkan data, total terdapat 35.8 persen masyarakat Desa Tamansari bekerja di sektor buruh industri/ buruh bangunan, dan rata-rata sektor industri tersebut mayoritas terdapat di luar wilayah Desa Tamansari.

Hal tersebut membuktikan bahwa Desa Tamansari belum memiliki sektor industri yang mampu menciptakan lapangan pekerjaan bagi para pemuda desa. Berdasarkan wawancara dengan Kepala Desa Tamansari, Lastuti pada 25 Februari 2019 mengenai ketersediaan lapangan kerja di sektor industri, bahwasanya Desa Tamansari belum memiliki industri yang 
mampu menciptakan lapangan kerja bagi masyarakat desa khususnya di kalangan para pemuda desa, kemudian aktivitas pemuda desa pada waktu itu juga sangat berpengaruh terhadap minimnya lapangan pekerjaan di desa, karena sebagaian besar aktivitas pemuda desa hanya aktif di organisasi-organisasi desa saja tanpa mampu memanfaatkan organisasi tersebut menjadi sesuatu hal yang lebih produktif dan bermanfaat bagi masyarakat desa, hal tersebut tidak sesuai dengan teori kewirausahaan yang disampaikan oleh Yusuf dkk (2016:47) yang menyatakan bahwa pemuda diharapkan mampu memaksimalkan semangat jiwa muda dalam sektor kewirausahaan dan menciptakan inovasi yang dapat bermanfaat untuk orang lain. Adapun kutipan wawancara tersebut yakni sebagai berikut:

"Peluang kerja industri di desa apa ya? Saya juga belum melihat peluang kerja industri di Desa pada waktu itu, kebanyakan anak-anak muda disini kerja di Industri idep (bulu mata) yang ada di Kabupaten. Kegiatan pemuda juga sangat berpengaruh, dahulu kegiatan pemuda belum produktif, kebanyakan pemuda hanya aktif di organisasi-organisasi yang ada di desa seperti Karang Taruna, Muhammadyah dan Nahdlatul Ulama, mangkanya saya selalu menekankan kepada mereka sampai sekarang setiap ada kumpulan untuk menciptakan kegiatan-kegiatan yang produktif, seperti tanah desa di kelola untuk warung atau apalah. (Wawancara dengan Kepala Desa Tamansari, Lastuti, pada 25 Februari 2019, Pukul 17.50 WIB)."

Kemudian berdasarkan data BPS (Badan Pusat Statistik) terakhir pada tahun 2015, Kabupaten Purbalingga mengenai sektor industri, sektor industri yang terdekat dengan Desa Tamansari hanya berada di wilayah pusat Kecamatan Karangmoncol yakni berjumlah 2 Industri, tetapi kedua sektor industri tersebut hanya mampu mempekerjakan sedikit sekali masyarakat desa di wilayah Kecamatan Karangmoncol yakni berjumlah 60 orang pekerja dari total keseluruhan masyarakat Kecamatan Karangmoncol.

\section{Penyebab Faktor Pemuda Desa Memilih} Bekerja Di Kota

Perpindahan seseorang untuk meninggalkan kampung halaman, tidak hanya disebabkan minimnya lapangan pekerjaan yang ada di desa, malainkan terdapat faktor lain yang menjadi daya tarik bagi seseorang untuk meyakinkan diri merantau dan bekerja di kota. Khususnya pemuda Desa Tamansari, terdapat penyebab yang menjadi alasan pemuda Desa Tamansari lebih memilih merantau dan bekerja di pusat kabupaten atau di beberapa kota besar yang terdapat di Indonesia, yakni salah satunya dari segi penghasilan yang diperoleh.

Data menunjukan bahwa penghasilan dari bekerja di kota jauh lebih besar jika dibandingkan penghasilan dari bekerja di desa. Alasan tersebut berdasarkan wawancara yang peneliti lakukan dari beberapa pemuda Desa Tamansari. Adapun kutipan wawancara tersebut yakni sebagai berikut:

"Dulu selain mencari lapangan pekerjaan di Desa makin susah, kalau ada juga gajinya kurang, kalau di Kota gajinya lebih besar gitu kan. (Wawancara dengan pemuda Desa Tamansari, Zaenal Sukri, pada 25 Februari 2019, Pukul 16.20 WIB).

"Kata temen di Kota gajinya gede. Kalau di desa paling gajinya 500/600, kalau di Kota kan UMR (Upah Minimum Regional). (Wawancara dengan pemuda Desa Tamansari, Apriliyani, pada 25 Februari 2019, Pukul 16.40 WIB)."

"Merantau karena kalau kerja di Kota pendapatanya lebih banyak, lebih besar jika dibandingkan dengan di Desa (Wawancara dengan pemuda Desa Tamansari, Endah Saputri Ningsih, pada 25 Februari 2019, Pukul 16.38 WIB).

Jika berdasarkan data UMK (Upah Minimum Kabupaten) di wilayah Provinsi 
Jawa Tengah tahun 2019, UMK Purbalingga berada pada peringkat 17 dari 35 wilayah Kabupaten yang ada di Jawa Tengah. UMK Purbalingga berada pada nominal Rp. 1.788.500,00-, UMK tersebut masih di bawah UMK Kota Semarang sebagai Ibu Kota Provinsi Jawa Tengah yang berada pada nominal Rp. 2.498.587,00-. Jika dibandingkan dengan beberapa kota besar yang ada di Indonesia seperti DKI Jakarta, UMK Purbalingga memiliki perbandingan setengah lebih dari UMK DKI Jakarta yang berada pada nominal Rp. 3.940.973,00- (Detiknews, 2018).

Oleh karena itu sangat relevan apabila masyarakat yang tinggal di desa lebih memilih untuk merantau ke kota karena penghasilan di desa jauh lebih kecil jika dibandingkan penghasilan apabila bekerja di pusat kabupaten atau beberapa kota besar yang ada di Indonesia. Hal tersebut sesuai dengan teori urbanisasi dari Shogo Kayono (dalam Harahap, 2013:36) yang menyatakan bahwa perpindahan penduduk dari desa ke kota atas suatu latarbelakang ekonomi

\section{SIMPULAN DAN SARAN}

Salah satu permasalahan yang kerap terjadi di desa adalah masalah pengangguran dan urbanisasi di kalangan pemuda desa, hal tersebut terjadi di kalangan pemuda Desa Tamansari, Kecamatan Karangmoncol, Kabupaten Purbalingga, Provinsi Jawa Tengah. Terdapat beberapa faktor yang melatarbelakangi terjadinya pengangguran dan urbanisasi di kalangan pemuda Desa, adapun beberapa faktor tersebut yakni (1) tidak melanjutkanya pemuda desa ke jenjang perguruan tinggi seusai menyelesaikan pendidikan menengah atas, (2) ketidakmauan para pemuda untuk bekerja di sektor pertanian meskipun sebagian besar memiliki orang tua yang mayoritas bekerja sebagai petani, (3) minimnya lapangan kerja di desa, (4) keinginan dan tekad kuat untuk bekerja di kota.

Terkait dengan alasan utama pemuda Desa Tamansari tidak melanjutkan ke jenjang perguruan tinggi yakni karena faktor masalah ekonomi keluarga yang tidak memadai untuk membiayai ke jenjang perguruan tinggi. Selanjutnya terkait dengan ketidakmauan para pemuda untuk bekerja di sektor pertanian meskipun sebagian besar memiliki orang tua yang mayoritas bekerja sebagai petani karena sektor pertanian di Desa Tamansari tidak mampu memberikan jaminan masa depan yang lebih baik, karena kecilnya penghasilan yang diperoleh dari sektor pertanian.

Kemudian terkait minimnya lapangan kerja di desa dikarenakan Desa Tamansari belum memiliki industri yang mampu menciptakan lapangan kerja bagi masyarakat desa khususnya di kalangan para pemuda desa, kemudian aktivitas pemuda desa pada waktu itu juga sangat berpengaruh terhadap minimnya lapangan pekerjaan di desa, karena sebagaian besar aktivitas pemuda desa hanya aktif di organisasi-organisasi desa saja tanpa mampu memanfaatkan organisasi tersebut menjadi sesuatu hal yang lebih produktif dan bermanfaat bagi masyarakat desa. Terakhir, terkait keinginan dan tekad kuat pemuda untuk bekerja di kota dikarenakan penghasilan yang diperoleh, data menunjukan bahwa penghasilan dari bekerja di kota jauh lebih besar jika dibandingkan penghasilan dari bekerja di desa.

\section{DAFTAR PUSTAKA}

Badan Pusat Statistik. (2017). Kecamatan Karangmoncol dalam Angka 2017. Purbalingga: Badan Pusat Statistik.

Badan Pusat Statistik. (2018). Kecamatan Karangmoncol dalam Angka 2018. Purbalingga: Badan Pusat Statistik.

CNN Indonesia. (2019). JK Sebut UMR Buruh Jauh Lebih Tinggi dari Pendapatan Petani. Diakses di https://www.cnnindonesia.com/ekono mi/20190228104826-92-373399/jksebut-umr-buruh-jauh-lebih-tinggidari-pendapatan-petani. Pada 1 Mei 2019 Pukul 09.00 WIB.

Detiknews. (2018). Ini Nominal UMK seJawa Tengah 2019 yang Diteken Ganjar. Diakses https://news.detik.com/berita-jawatengah/d-4312799/ini-nominal-umkse-jawa-tengah-2019-yang-diteken- 
ganjar. Pada 10 Maret 2019 Pukul 13.35 WIB.

Dongoran, F.R., Nisa, Khairul., Sihombing, Marni., Purba, L.D. (2016). Analisis Jumlah Pengangguran Dan Ketenagakerjaan Terhadap Keberadaan Usaha Mikro Kecil Dan Menengah Di Kota Medan. Jurnal EduTech Vol. 2 No. 2 September 2016.

Fransiska, Hengky Emanuel. (2018). Peran Guru Pendidikan Pancasila Dan Kewarganegaraan (PPKn) Dalam Mendukung Progam Bela Negara Dan Implikasinya Terhadap Ketahanan Pribadi Siswa (Studi Pada Guru PPKn Dan Siswa Di SMAN 1 Banguntapan Kabupaten Bantul, Daerah Istimewa Yogyakarta), Tesis: Universitas Gadjah Mada.

Harahap, R., \& Sos, S. (2013). Dampak urbanisasi bagi perkembangan kota di Indonesia. Jurnal Society UBB, Vol. 1, No. 1, Tahun 2013.

Hidayat, A.C. (2016). Strategi Memenangkan Persaingan Global Dengan Mengubah Keunggulan Komparatif Menjadi Keunggulan Kompetetif. Prosiding Seminar STIAMI, Vol. 3, No. 01, Februari 2016.

Katadata. (2019). Tingkat Urbanisasi Indonesia Dalam Kategori Menegah. Diakses

https://databoks.katadata.co.id/datapu blish/2019/10/08/tingkat-urbanisasiindonesia-dalam-kategori-menengah. Pada 17 Mei 2020 Pukul 07.00 WIB.

Katadata. (2020). Angka pengagguran di Desa Meningkat. Diakses di https://databoks.katadata.co.id/datapu blish/2020/05/11/angka-

pengangguran-di-desa-meningkat. Pada 17 Mei 2020 Pukul 07.30 WIB.

Nugroho, R. W. A. (2018). Keterlibatan Pemuda Dalam Keberhasilan Usaha Kecil Dan Kontribusi Pendapatannya Terhadap Ketahanan Ekonomi Keluarga (Studi Pada Usaha Kecil Kerajinan Tembaga Bangun Karya Di Krapyak Wetan, Panjangrejo, Pundong, Bantul, Daerah Istimewa Yogyakarta), Tesis: Universitas Gadjah Mada.
Okezone. (2017). Petani Masih Miskin! Rata-Rata Pendapatannya Rp1 Juta/Bulan. Diakses di https://economy.okezone.com/read/20 17/05/04/320/1682953/petani-masihmiskin-rata-rata-pendapatannya-rp1juta-bulan. Pada 1 Mei 2019 Pukul 08.30 WIB.

Pujianto, D., Rustiarso., Husni Syahrudin. (2015). Faktor-Faktor Penyebab Anak Tidak Melanjutkan Pendidikan Ke Perguruan Tinggi. Jurnal Pendidikan Dan Pembelajaran, Vo.l 4, No. 9, hal. 1-15, September 2015.

Ramdani, D.. (2014). Pelaksanaan Program Pemuda Sarjana Penggerak Pembangunan Di Pedesaan (Psp-3) Dalam Meningkatkan Kemandirian Kewirausahaan Pemuda Dan Implikasinya Terhadap Ketahanan Ekonomi Wilayah (Studi Di Kecamatan Dlingo, Kabupaten Bantul DI Yogyakarta). Jurnal Ketahanan Nasional, Vol. 20, No.3, Hal. 15-26, Tahun 2014.

Sukirno, Sadono. (1994). Pengantar Makro Ekonomi. Jakarta : Penerbit Raja Grafindo.

Sukirno, Sadono. (2008). Mikroekonomi: Teori Pengantar. Edisi Ketiga. Jakarta: PT Raja Grafindo Persada.

Susilowati, S. H. 2016. Fenomena Penuaan Petani Dan Berkurangnya Tenaga Kerja Muda Serta Implikasinya Bagi Kebijakan Pembangunan Pertanian. Jurnal Penelitian Agro Ekonomi, Vol. 34, No. 1, Hal. 35-55, Juni 2016.

Tjiptoherijanto, P. (1999). Urbanisasi dan Pengembangan Kota di Indonesia. Populasi, Vol. 10, No. 2, Tahun 1999.

Undang-Undang Republik Indonesia Nomor 40 Tahun 2009 Tentang Kepemudaan. (2019). Basis Hukum. Diakses di https://www.basishukum.com/uu/40/2 009. Pada 1 Februari 2019 Pukul 10.00 WIB.

Yusuf, I. F., Edhi Martono., Agus Prasetya. (2016). Peran Pemuda Dalam Pengembangan Eduwisata Energi Terbarukan Dan Implikasinya Terhadap Ketahanan Ekonomi Wilayah (Studi di Desa Poncosari Kecamatan Srandakan Kabupaten 
p-ISSN : 2599-1418

Jurnal Pendidikan Ekonomi Undiksha

e-ISSN : 2599-1426

Vol. 12 No. 1 (2020)

Bantul Daerah Istimewa Yogyakarta).

Jurnal Ketahanan Nasional, Vol. 22,

No. 3, Hal. 285-305, Tahun 2016. 